\title{
Failure to improve parameters of lactose maldigestion using the multiprobiotic product VSL3 in lactose maldigesters: A pilot study
}

\author{
Rose Yesovitch BSc, Albert Cohen MD FRCPC, Andrew Szilagyi MD FRCPC
}

R Yesovitch, A Cohen, A Szilagyi. Failure to improve parameters of lactose maldigestion using the multiprobiotic product VSL3 in lactose maldigesters: A pilot study. Can J Gastroenterol 2004;18(2):83-86.

Lactose maldigestion is a common genetic trait in up to $70 \%$ of the world's population. In these subjects, the ingestion of lactose may lead to prebiotic effects which can be confirmed by measurement of breath hydrogen. After a period of continuous lactose ingestion, colonic bacterial adaptation is measurable as improved parameters of lactose digestion. There may be inherent benefits in this process of adaptation which may protect against some diseases. We attempt to link therapeutically beneficial probiotics (VSL3, Seaford Pharmaceuticals Inc, Ontario) with improvement in parameters of lactose maldigestion. Two groups of five subjects with maldigestion were fed one or four packets of VSL3 (one packet containing $450 \times 10^{9}$ live bacteria) before testing and then 17 days later. A $50 \mathrm{~g}$ lactose challenge was carried out before and after feeding. While there was a trend toward increasing rather than reducing of summed breath hydrogen, no statistically significant changes were observed between results from before testing and those from testing 17 days later. The authors conclude that direct consumption of the probiotic VSL3 may not improve parameters of lactose maldigestion without metabolic activation. In its present format, therefore, the test for colonic adaptation cannot be used to demonstrate direct bacterial embedding with VSL3.

Key Words: Lactose intolerance; Probiotics therapy
L'incapacité d'améliorer les paramètres de la mauvaise digestion du lactose au moyen du VSL3, un produit multiprobiotique, chez ceux qui le digèrent mal : Un projet-pilote

La mauvaise digestion du lactose est une caractéristique génétique courante, atteignant jusqu'à $70 \%$ de la population mondiale. Chez ces sujets, l'ingestion de lactose peut provoquer des effets prébiotiques qui peuvent être confirmés par la mesure de l'hydrogène respiratoire. Après une période d'ingestion continue de lactose, l'adaptation bactérienne du côlon peut être mesurée sous forme d'amélioration des paramètres de digestion du lactose. On peut remarquer des bénéfices inhérents à ce processus d'adaptation qui peut assurer une protection contre certaines maladies. Nous tentons de relier des probiotiques au potentiel bénéfique (VSL3, Seaford Pharmaceuticals Inc., Ontario) à l'amélioration des paramètres de mauvaise digestion du lactose. Deux groupes de cinq sujets ayant des troubles digestifs ont reçu un ou quatre paquets de VSL3 (un paquet correspondant à $450 \times 10^{9}$ bactéries vivantes) avant le test, puis 17 jours plus tard. Une provocation par $50 \mathrm{~g}$ de lactose a été effectuée avant et après l'ingestion. Bien qu'on ait remarqué une tendance vers l'accroissement plutôt que la diminution de l'hydrogène respiratoire total, aucune modification statistiquement significative n'a été observée entre les résultats obtenus avant le test et ceux obtenus 17 jours plus tard. Les auteurs concluent que la consommation directe du probiotique VSL3 n'améliore peut-être pas les paramètres de mauvaise digestion du lactose sans activation métabolique. Ainsi, dans sa forme actuelle, le test d'adaptation du côlon ne peut être utilisé pour démontrer un enrobage bactérien direct par le VSL3.

$\mathrm{T}$ he concept of prebiotics was suggested by Gibson and Roberfroid (1). It is based on the theory that some undigested nutrients (usually polysaccharides) which bypass the upper gastrointestinal tract specifically alter the metabolism and expand bacterial populations (usually lactic acid-producing bacteria) thought to exert beneficial effects on the host. There are a number of known natural (those found in leeks, hickory, onions [1] and breast milk [2]) and manufactured (eg, transgalactoliposaccharides [3] and lactulose [4]) prebiotics. Lactose in lactose maldigesters (lactase nonpersistent [LNP] subjects) may be a conditional natural prebiotic because approximately $67 \%$ to $70 \%$ of the world's population lose the ability to digest lactose (5). In these LNP subjects it has been reported that continued lactose consumption leads to improved handling of the disaccharide $(6,7)$. The

phenomenon of improved lactose tolerance on rechallenge after consuming lactose for a defined period of consumption is putatively due to colonic bacterial alteration of metabolism and expansion of targeted microbial flora $(7,8)$. This process is termed colonic adaptation and is defined clinically by reduced measured breath hydrogen $\left(\mathrm{H}_{2}\right)$ after rechallenge with the target sugar (in this case lactose) (7). Improved symptoms of intolerance and increased fecal $\beta$-galactosidase also constitute part of adaptation. In vitro data suggest that adding Lactobacillus or Bifidobacteria species to an adapting system facilitates lactose digestion $(9,10)$. Furthermore, there is a single study suggesting that $\mathrm{H}_{2}$ production is reduced on lactulose rechallenge after consuming lactobacillus parvum 299V (11). Lactulose and lactose may exert similar effects on colonic bacteria (12).

Division of Gastroenterology, Department of Medicine, McGill University School of Medicine, Montreal, Quebec

Correspondence and reprints: Dr A Szilagyi, The Sir Mortimer B Davis Jewish General Hospital, 3755 Cote St Catherine Road, Room G-327,

Montreal, Quebec H3T 1E2. Telephone 514-340-8144, fax 514-340-8282, e-mail aszilagy@gas.jgh.mcgill.ca

Received for publication October 13, 2003. Accepted December 17, 2003 
Although beneficial in its own right (improved nutritional assimilation) the process of adaptation and measurement of resulting breath $\mathrm{H}_{2}$ may be used as a functional test of colonic bacterial status. For example, we recently showed that patients with inflammatory bowel disease (IBD) in remission are slow or unable to adapt to lactulose, as are healthy controls based on the above outlined concept (13). This adaptive test supports the notion that flora in IBD is abnormal $(14,15)$.

In an effort to further evaluate the potential of colonic adaptation as a biological test of colonic floral function we attempted to link the test with a probiotic of suggested benefit in IBD. The eight-probiotic-containing product VSL3 (Seaford Pharmaceucticals Inc, Ontario) has been shown to be therapeutically useful in pouchitis $(16,17)$ and ulcerative colitis in remission $(18,19)$, and preliminary data show benefit in active ulcerative colitis (20). We therefore undertook a small pilot study and fed two doses of VSL3 to subjects with known lactose maldigestion. However, no improvement was found.

\section{SUBJECTS AND STUDY DESIGN}

Ten healthy paid volunteers of multiethnic origin who were previously established to be lactose maldigesters (four men, six women; mean age of $38.6 \pm 14.6$ years) were recruited. The subjects underwent two lactose $(50 \mathrm{~g})$ challenge tests. The first was followed by ingestion of VSL3 bacteria and then a second similar challenge test was carried out at the end of the adapting period after 17 days. The 17-day period was arbitrarily chosen based on the previously published observation that adaptation is associated rapidly with altered floral microorganisms with lactose (8). Secondly, two other studies using naïve probiotics $(21,22)$ showed that bacteria were readily cultured from stool in a short period of time (one week or less). Five subjects consumed $1 \mathrm{~g}\left(450 \times 10^{9}\right)$ of the bacteria and the other five consumed $4 \mathrm{~g}\left(4 \times 450 \times 10^{9}\right)$ bacteria. Bacteria were usually mixed with water and taken with meals. The side effects were minor and consisted mainly of nausea, mostly in the high dose group.

The VSL3 probiotic contains four strains of Lactobacillus ( $L$ casei, $L$ plantarum, $L$ acidophilus and $L$ bulgaricus), three of Bifidobacterium (B longum, B breve and B infantis), and one strain of Streptococcus salivarius subspecies thermophilus. The probiotics were a gift of Dr C De Simone (Italy) via Seaford Pharmaceuticals Inc (Ontario). Three random batches were checked for viability by plating the contents of a packet on standard blood agar plates. The microbiological evaluation was carried out in the Mortimer B Davis Jewish General Hospital hospital laboratory under the supervision of Dr M Miller.

Informed consent was obtained from all participants and this study was approved by the Research Ethics Committee of the Sir Mortimer B Davis Jewish General Hospital.

\section{Lactose challenge tests}

After a specified supper (with avoidance of lactose gas-forming foods; rice and hamburger were suggested) volunteers were asked to fast (water ad libitum). None of the volunteers took antibiotics, analgesics or any anti- or prokinetic medications. They were asked not to chew gum or smoke but were allowed quiet movement throughout a $4.5 \mathrm{~h}$ measurement of exhaled $\mathrm{H}_{2}$. A $50 \mathrm{~g}$ lactose load mixed in water was consumed and after a baseline measurement, breath $\mathrm{H}_{2}$ was measured every $30 \mathrm{~min}$ using a validated handheld $\mathrm{H}_{2}$ electrochemical sensor (EC60 Vitalograph hydrogen breath monitor, Bedfont Scientific Ltd, United Kingdom) (23,24). The model uses a sealed electrochemical sensor which can detect $\mathrm{H}_{2}$ in parts per million (ppm) v/v in a range of $0 \mathrm{ppm}$ to $2000 \mathrm{ppm}$. The average of three exhaled breaths was used at each time interval. Results at each interval were corrected by subtracting the baseline $\mathrm{H}_{2}$ ppm. In addition, symptoms were recorded by subjects each half hour and graded. The targeted symptoms were bloating, gas, cramps and diarrhea. For each, a score of 1 was assigned for mild (subject aware), 2 for definite presence and 3 for severe symptoms. Although theoretically the maximum score was $108(9 \times 12$ periods $)$ it is virtually impossible to score 12 at each interval. Therefore, for practical purposes, the score system was an open-ended scale. In the case of diarrhea, each loose bowel movement was scored every $30 \mathrm{~min}$. This ordinal scale system was used by the authors previously (12). At the end of 17 days, subjects were asked to repeat the $50 \mathrm{~g}$ lactose challenge and record symptoms (test 2).

\section{Statistical analysis}

Student's paired $t$ tests were used to analyze differences between test 1 and test 2 in both groups. Based on the authors' previous experience of inducing colonic adaptation with lactulose at low dose, it was reasoned that eight to 10 patients per group would suffice to demonstrate a significant difference of a $45 \%$ reduction in the sum of breath $\mathrm{H}_{2}$ on test 2 . This difference was chosen because we previously showed (12) that using lactulose as a prebiotic a reduction of $43 \%$ between two challenge doses of lactose was statistically significant (12). While this difference may or may not be clinically significant at an individual level for lactose tolerance, it clearly allows demonstration of a population test effect on colonic microbial function. In fact, in our original abstract, six subjects already demonstrated a statistically significant trend at $\mathrm{P}=0.054$ (25). Pearson correlation was used to compare symptoms with sum of breath $\mathrm{H}_{2}$. Statistical significance was accepted at $\mathrm{P}<0.05$.

\section{RESULTS}

Four men and six women with a mean age of $38.6 \pm 14.6$ years (range 24 to 66) undertook the studies. The average baseline $\mathrm{H}_{2}$ ppm in test 1 was $0.8 \mathrm{ppm}$ (range 0 to 2$)$ in test $1(\mathrm{n}=10)$ and $4.5 \mathrm{ppm}$ (range 0 to 16$)$ in test $2(\mathrm{n}=10)$. Changes in $\Sigma 4 \mathrm{~h}$ breath $\mathrm{H}_{2}$ and symptom scores for the individuals in group I (one packet/day VSL3) and group II (four packets/day VSL3) are shown in Table 1 . Mean \pm SD for $\Sigma 4$ h breath $\mathrm{H}_{2}$ for test 1 was $279.8 \pm 16.4$ (CI 256 to 297) for group I, and $323 \pm 158.9$ (CI 192 to 597) for group II. In test $2 \Sigma 4.5 \mathrm{~h}$ breath $\mathrm{H}_{2}$ for group I was $302 \pm 157.8$ (CI 152 to 480 ) and group II $401.0 \pm 198.8$ (CI 139 to 682 ). While these differences were statistically insignificant, there was a trend for higher rather than lower $\Sigma 4.5 \mathrm{~h}$ breath $\mathrm{H}_{2}$ on test 2 in group II. Similarly, there were no statistically significant changes in symptom score for either group I or group II. While there was a weak significant correlation between global symptom scores for both groups in test $1(\mathrm{r}=0.65)$, this possible relationship was lost in test $2(\mathrm{r}=0.131)$. Random cultures of probiotics showed that the ingested products were viable.

\section{DISCUSSION}

This small pilot study did not show any benefit for improving lactose intolerance under laboratory conditions. Nevertheless, we felt it is still valuable to report it because of the principle involved in the logic of such studies. 
TABLE 1

\begin{tabular}{|c|c|c|c|c|c|c|}
\hline Patient & Sex & Age & Test $1 \mathrm{BH}_{2}$ & Test 1 ss & Test $2 \mathrm{BH}_{2}$ & Test 2 ss \\
\hline 1 & $\mathrm{~F}$ & 25 & 272 & 16 & 172 & 14 \\
\hline 2 & $M$ & 40 & 282 & 14 & 480 & 35 \\
\hline 3 & $\mathrm{~F}$ & 45 & 256 & 35 & 245 & 32 \\
\hline 4 & $M$ & 24 & 292 & 63 & 152 & 70 \\
\hline 5 & M & 34 & 297 & 31 & 461 & 6 \\
\hline Mean \pm & EM & & $279.8 \pm 7.4$ & $31.8 \pm 8.8$ & $302 \pm 70.6$ & $31.4 \pm 11.1$ \\
\hline 6 & $\mathrm{~F}$ & 53 & 307 & 13 & 429 & 33 \\
\hline 7 & $\mathrm{~F}$ & 32 & 192 & 25 & 313 & 21 \\
\hline 8 & $\mathrm{~F}$ & 42 & 274 & 21 & 446 & 29 \\
\hline 9 & $\mathrm{~F}$ & 61 & 597 & 67 & 682 & 50 \\
\hline 10 & M & 66 & 245 & 10 & 139 & 10 \\
\hline Mean \pm & EM & & $323 \pm 71$ & $27.2 \pm 10.3$ & $401 \pm 88.9$ & $28.6 \pm 6.6$ \\
\hline
\end{tabular}

None of the differences were statistically significant. However, the $P$ value was 0.76 for $\Sigma 4.5 \mathrm{~h} \mathrm{BH}_{2}$ in group I and 0.18 in group II comparing mean $\mathrm{BH}_{2}$ for test 1 versus test 2, respectively. F Female; M Male

To date, the only successful studies showing improvement of lactose maldigestion with probiotics are those using yogurt (26), other fermented products $(27,28)$ or the addition of live probiotics to milk $(29,30)$. The mechanism in improvement is thought to be due to three factors. First, fermented products contain 30\% less lactose. Second, the enzyme $\beta$-galactosidase is provided exogenously and continues to digest lactose in the small bowel of LNP subjects. Finally, yogurt may delay gastric emptying and intestinal transit time, thereby reducing the fractional quantity of lactose at the cecum (26). Delayed rate of delivery is putatively associated with reduced symptoms $(31,32)$.

Providing probiotics directly removes the physiological attributes of fermented products. The results obtained here and noted in the literature $(21,22)$ stand in stark contrast to the ability to cause colonic adaptation and improvement in lactose maldigestion with continued lactose consumption $(6,7)$. The process of adaptation with lactose alters fecal flora and favours the emergence of Lactobacillus and Bifidobacteria species (8).

The specific rationale of using VSL3 is that this probiotic has been successfully used therapeutically in IBD (16-20). In the paradigm of providing naïve probiotics, the following assumptions are made: in lactose maldigesters minimal or zero consumption of lactose may lead to decreased populations of putatively beneficial bacteria; with regular consumption of lactose such bacteria are now numerically expanded and metabolically activated; and if such bacteria (Lactobacillus and Bifidobacteria) are now given with fermented products or even unfermented milk they may become metabolically activated, facilitating lactose consumption before colonic embedding. If we now wish to establish that unique expansion of an important disease-beneficial bacteria is necessary for enhanced metabolism of lactose on challenge, prestimulation would abrogate such a conclusion. In vitro evidence suggests that infusion of naïve Lactobacillus or Bifidobacteria aids in consumption of lactose in fecal slurries $(9,10)$. It is not unreasonable to try to reproduce this effect in vivo.

There are indeed few studies that have examined the possible impact of direct probiotics on lactose maldigestion. Hove et al (21) used simultaneous addition of 12 capsules of mixed
Lactobacillus and Bifidobacteria species to a $50 \mathrm{~g}$ lactose challenge test. They did not find any improvement in breath $\mathrm{H}_{2}$ despite previously demonstrating the ability to recover bacteria from stool. More recently, Saltzman et al (22), in a similar elaborate study used a special $L$ acidophilus $\mathrm{BG} 2 \mathrm{FO} 4$ species (possessing a high $\beta$-galactosidase content) which too was cultured from stool after seven days in lactose maldigesters. However, breath $\mathrm{H}_{2}$ tests at the end did not differ significantly from the beginning, although the sum did increase on the second challenge test (22).

In our own study we also were unable to confirm adaptation by directly providing probiotics. While we were not able to verify colonic bacterial embedding with VSL3 it has been published that such bacteria are cultured from stool after 20 days (33). We feel that some bacterial embedding did occur in the present study because our 17-day adaptation period is close to 20 days and stools were not tested between 10 and 20 days after commencement of feeding, leaving open the possibility of earlier embedding (32). Furthermore, a dose response is suggested to have occurred in the current study because of a noted trend toward increased breath $\mathrm{H}_{2}$ production with a higher dose of bacteria. This finding was similar to that in the report by Saltzman et al (22).

A longer feeding period and achievement of our intended group sizes may have strengthened our results. It is important to note, however, that the observed trend showed an outcome opposite to what we were expecting. Therefore, achieving a significant difference with the currently observed trend would not have helped our goal. As a result, based on the reports from the literature and this study, we can cautiously conclude that providing metabolically naïve probiotics will not improve lactose maldigestion.

\section{CONCLUSION}

This pilot study does not provide a quick link test connecting probiotic-induced colonic adaptation and bacteria proven to be beneficial in therapy of IBD. Despite the limitations of this small pilot study, the results mimic those reported for other efforts to induce improvement in lactose handling by providing naïve probiotics directly. The uniformity of failure suggests that targeted bacteria to date need to be metabolically turned on before demonstrating efficacy. However future studies should include a longer colonic embedding period to determine whether metabolism of lactose might be altered over the extended time.

ACKNOWLEDGEMENT: We thank Dr Mark Miller for microbiological evaluations; Ms Blanka Glowacki for library assistance; Ms Antoinette Colacone, BSc, CCRA, and Dr Ian Shrier for statistical assistance; and Ms Florence Lurie and Ms Heather C Overal for expert secretarial service.

\section{REFERENCES}

1. Gibson GR, Roberfroid MB. Dietary modulation of the human colonic microbiota: Introducing the concept of prebiotics. J Nutr 1995;125:1401-12.

2. Newburg DS. Do the bindng properties of oligosaccharides in milk protect human infants from gastrointestinal bacteria? J Nutr 1997;127(Suppl 5):980S-4S.

3. Ito M, Deguchi Y, Matsumoto K, Kimura M, Onodera N, Yajima T. Influence of galactooligosaccharides on the human fecal microflora. J Nutr Sci Vitaminol (Tokyo) 1993;39:635-40.

4. Clausen MR, Mortensen PB. Lactulose disaccharides and colonic flora. Drugs 1997;53:930-42. 
5. Scrimshaw NS, Murray EB. The acceptability of milk and milk products in populations with a high prevalence of lactose intolerance. Am J Clin Nutr 1988;48(Suppl):1079-159.

6. Pribila BA, Hertzler SR, Martin BR, Weaver CM, Savaiano DA. Improved lactose digestion and intolerance among AfricanAmerican adolescent girls fed a dairy-rich diet. J Am Diet Assoc 2000;100:524-28

7. Hertzler SR, Savaiano DA. Colonic adaptation to daily lactose feeding in lactose maldigesters. Am J Clin Nutr 1996;64:232-6.

8. Ito M, Kimura M. Influence of lactose on faecal microflora in lactose maldigesters. Microbial Ecol Health Dis 1993;6:73-6.

9. Jiang T, Savaiano DA. In vitro lactose fermentation by human colonic bacteria is modified by Lactobacillus acidophilus supplementation. J Nutr 1997;127:1489-95.

10. Jiang T, Savaiano DA. Modification of colonic fermentation by bifidobacteria and $\mathrm{pH}$ in vitro impact on lactose metabolism shortchain fatty acid, lactate production. Dig Dis Sci 1997;42:2370-7.

11. Sen S, Mullan MM, Parker TJ, Woolner JT, Tarry SA, Hunter JO. Effect of Lactobacillus plantarum 299v on colonic fermentation and symptoms of irritable bowel syndrome. Dig Dis Sci 2002:47:2615-20

12. Szilagyi A, Rivard J, Fokeeff K. Improved parameters of lactose maldigestion using lactulose. Dig Dis Sci 2001;46:1509-19.

13. Szilagyi A, Rivard J, Shrier I. Diminished efficacy of colonic adaptation to lactulose occurs in patients with inflammatory bowel disease in remission. Dig Dis Sci 2002;47:2811-22.

14. Favier C, Neut C, Mizon C, Cortot A, Colombel JF, Mizon J. Fecal beta-D-galactosidase production and Bifidobacteria are decreased in Crohn's disease. Dig Dis Sci 1997;42:817-22.

15. Carrette O, Favier C, Mizon C, et al. Bacterial enzymes used for colon-specific drug delivery are decreased in active Crohn's disease. Dig Dis Sci 1995;40:2641-6.

16. Gionchetti P, Rizzello F, Venturi A, et al. Oral bacteriotherapy as maintenance treatment in patients with chronic pouchitis: A double-blind, placebo-controlled trial. Gastroenterology 2000;119:305-9.

17. Gionchetti P, Rizzello F, Helwig U, et al. Prophylaxis of pouchitis onset with probiotic therapy: A double-blind, placebo-controlled trial. Gastroenterology 2003;124:1202-9.

18. Kruis W, Schutz E, Fric P, Fixa B, Judmaier G, Stolte M. Doubleblind comparison of an oral Escherichia coli preparation and mesalanine in maintaining remission of ulcerative colitis. Aliment Pharmacol Ther 1997;11:853-8.

19. Rembacken BJ, Snelling AM, Kawkey PM, Chalmers DM, Axon AT. Non-pathogenic Escherichia coli versus mesalazine for the treatment of ulcerative colitis: A randomized trial. Lancet 1999;354:635-9.

20. Fedorak RN, Gionchetti P, Campieri M, et al. VSL3 probiotic mixture induces remission in patients with active ulcerative colitis. Gastroenterology 2003;124:A377.

21. Hove H, Norgaad-Andersen I, Mortensen PB. Effect of lactic acid bacteria on the intestinal production of lactate and short-chain fatty acids, and the absorption of lactose. Am J Clin Nutr 1994;59:74-9.

22. Saltzman JR, Russel RM, Golner B, Barakat S, Dallal GE, Goldin BR. A randomized trial of Lactobacillus acidophilus BG2FO4 to treat lactose intolerance. Am J Clin Nutr 1999;69:140-6.

23. Metz G, Gassull MA, Leeds AR, Blendis LM, Jenkins DJ. A simple method of measuring breath hydrogen in carbohydrate malabsorption by end-expiratory sampling. Clin Sci Mol Med 1976;50:237-40.

24. Van der Klei-van Moorsel JM, Douwes AC, van Oeveren JP. New principle for estimation of hydrogen in expired air. Eur J Pediatr 1984;141:221-4

25. Szilagyi A, Rivard J. Improved lactose maldigestion by adaptation with lactulose crystals: Crossadapt study. Gastroenterology 2000;118:A776.

26. de Vrese M, Stegelman A, Richter B, Fenselau S, Laue C, Scherenmeir J. Probiotics - compensation for lactase insufficiency. Am J Clin Nutr 2001;73(Suppl 2):421S-9S.

27. Bouhnik Y, Flourie B, Andrieux C, Biselli N, Briet F, Rambaud J-C. Effects of Bifidbacterium sp fermented milk ingested with or without inulin on colonic bifidobacteria and enzymatic activities in healthy humans. Eur J Clin Nutr 1996;50:269-73.

28. Hertzler SR, Clancy SM. Kefir improves lactose digestion and tolerance in adults with lactose maldigestion. J Am Diet Assoc 2003;103:582-7.

29. Lin M-Y, Yen C-L, Chen S-H. Management of lactose maldigestion by consuming milk containing lactobacilli. Dig Dis Sci 1998;43:133-7.

30. Jiang T, Mustapha A, Savaiano DA. Improvement of lactose digestion in humans by ingestion of unfermented milk containing Bifidobacterium longum. J Dairy Sci 1996;79:750-7.

31. Szilagyi A, Salomon R, Seidman E. Influence of loperimide on lactose handling and oral-caecal transit time. Aliment Pharmacol Ther 1996;10:765-70.

32. Read NW, Al-Janabi MN, Bates TE, et al. Interpretation of the breath hydrogen profile obtained after ingesting a solid meal containing unabsorbable carbohydrate. Gut 1985;26:834-42.

33. Venturi A, Gionchetti P, Rizzello F, et al. Impact on the composition of the faecal flora by a new probiotic preparation: Preliminary data on maintenance treatment of patients with ulcerative colitis. Aliment Pharmacol Ther $1999 ; 13: 1103-8$ 


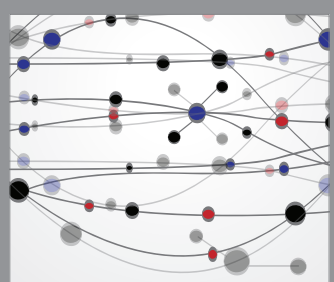

The Scientific World Journal
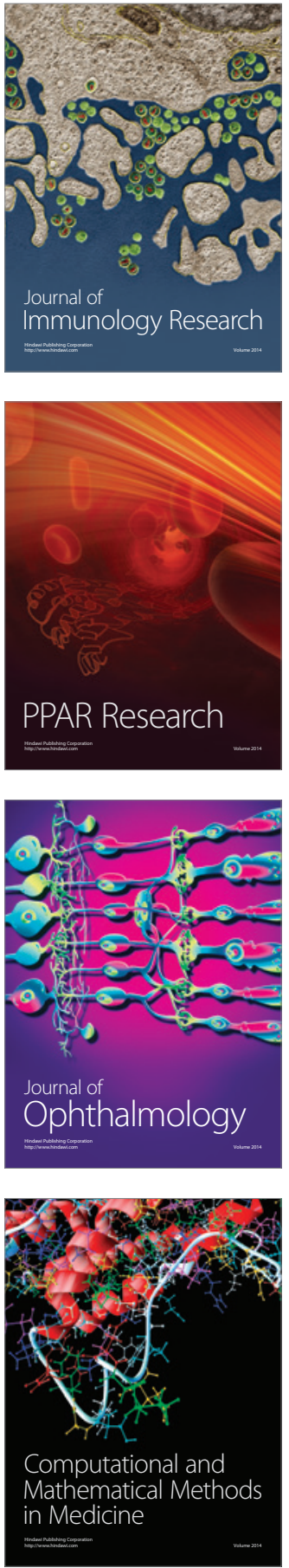

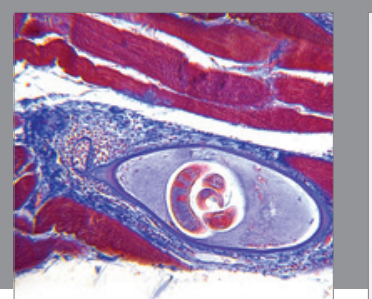

Gastroenterology Research and Practice

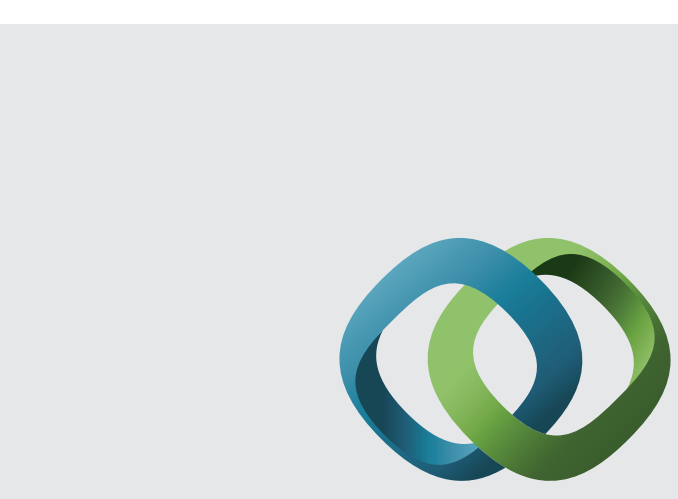

\section{Hindawi}

Submit your manuscripts at

http://www.hindawi.com
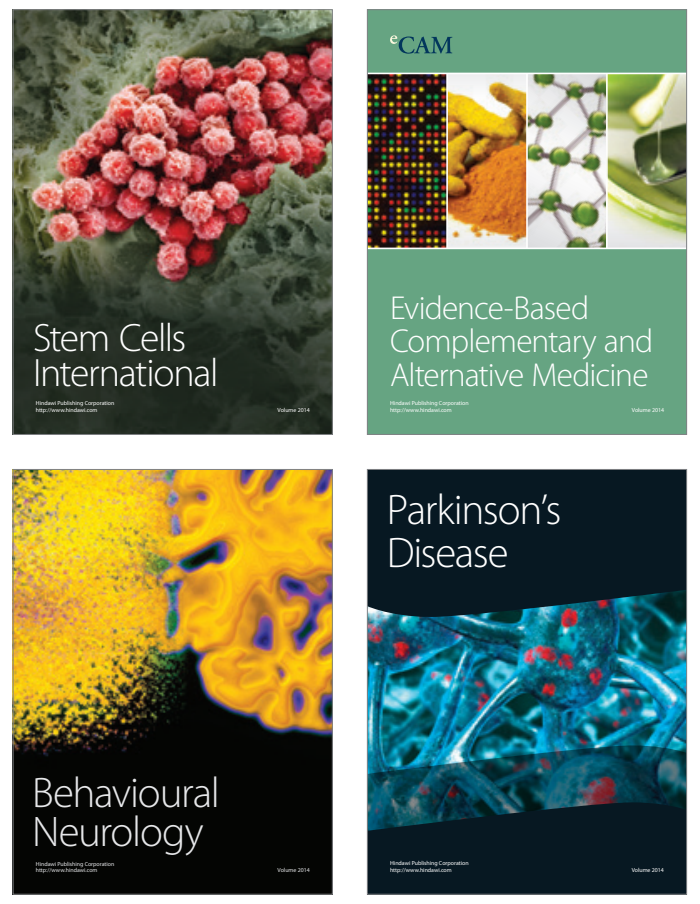
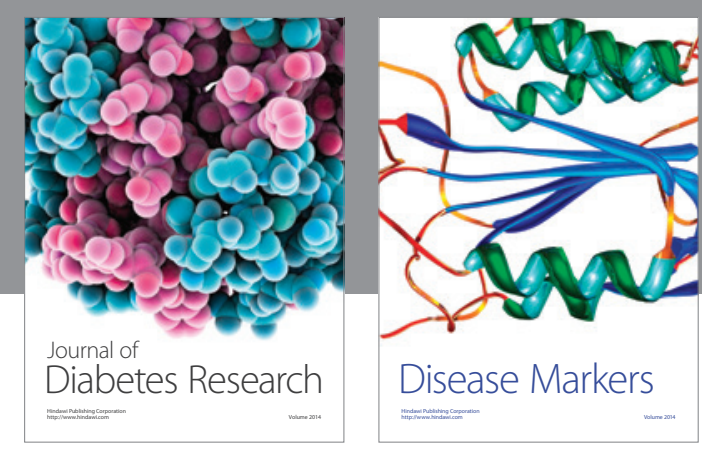

Disease Markers
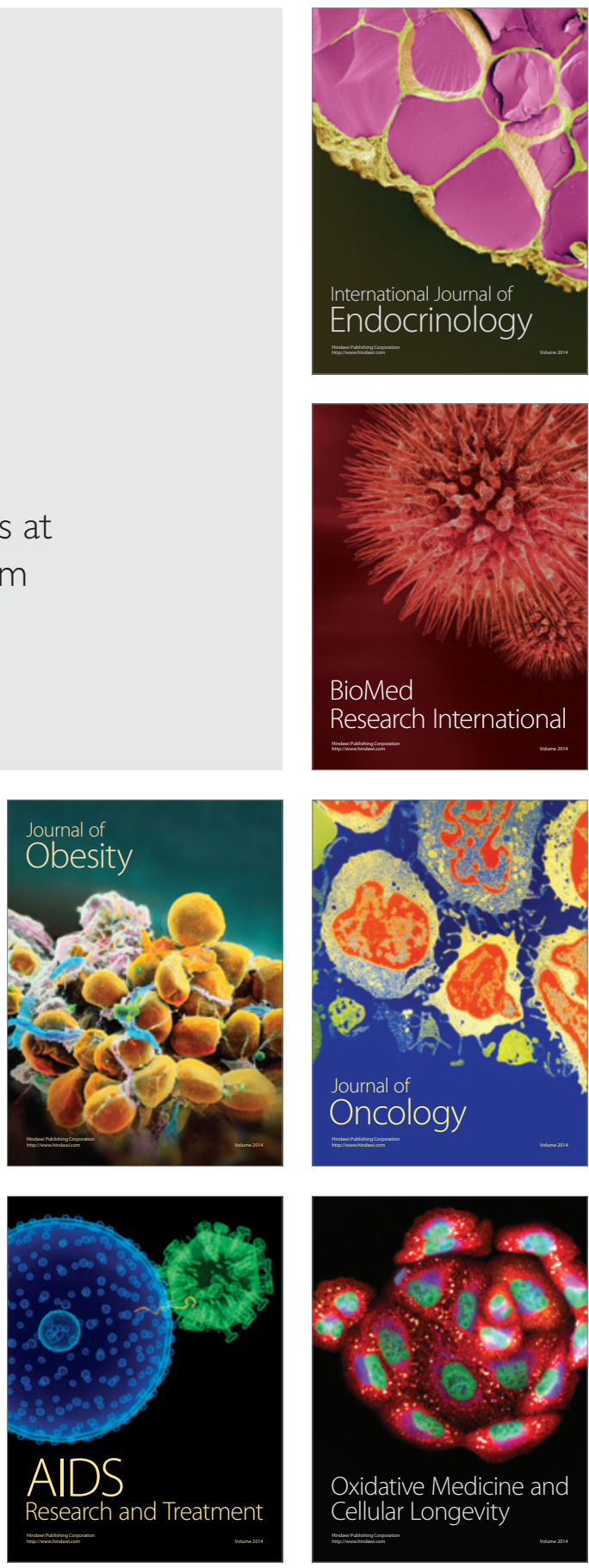